\title{
ANALISA PENGARUH ULASAN ONLINE SURABAYA PATATA TERHADAP PERCEIVED $e$-WOM CREDIBILITY
}

\author{
Evania Devita Genial ${ }^{1}$, Tasia Oktaviani ${ }^{2}$, Adriana Aprilia ${ }^{3 *}$ \\ ${ }^{1,2,3}$ Program Manajemen Perhotelan, Fakultas Bisnis dan Ekonomi \\ Universitas Kristen Petra, Surabaya \\ E-mail: ${ }^{1}$ evaniagenial@gmail.com; ${ }^{2}$ tasiaoktaviani@gmail.com; ${ }^{3}$ aprilia@petra.ac.id \\ *Penulis korespondensi
}

\begin{abstract}
Abstrak
Tujuan penelitian ini untuk mengetahui pengaruh faktor penentu informasi dan normatif ulasan online Surabaya Patata, yaitu argument strength, recommendation framing, recommendation sidedness, source credibility, confirmation of prior belief, dan recommendation consistency terhadap perceived eWOM credibility. Penelitian ini adalah penelitian kuantitatif kausal. Pengumpulan data didapat dari kuesioner yang disebarkan kepada 176 pembaca ulasan online Surabaya Patata. Hasil penelitian menunjukkan recommendation sidedness dan source credibility berpengaruh positif dan signifikan terhadap perceived eWOM credibility, serta source credibility memiliki pengaruh paling dominan.
\end{abstract}

Kata kunci: Electronic-word-of-mouth (eWOM)' ulasan online'; kredibilitas; faktor penentu informasi dan normatif eWOM.

\begin{abstract}
The purpose of this research was to determine the effect of information and normative determinants of online reviews Surabaya Patata, where are, argument strength, recommendation framing, recommendation sidedness, source credibility, confirmation of prior belief, and recommendation consistency significantly to perceived eWOM credibility. This type of research is quantitative causal. The data in this research were obtained from questionnaires distributed to 176 readers of online reviews about Surabaya Patata. The result show that recommendation sidedness and source credibility have significant positive effect toward perceived eWOM credibility, also source credibility has the most dominant effect.
\end{abstract}

Keywords: Electronic-word-of-mouth (eWOM); online review; credibility; information; normative and determinants.

\section{PENDAHULUAN}

Perkembangan teknologi yang semakin pesat khususnya pada era digital ini, membuat sebagian besar masyarakat, khususnya di Indonesia, menggunakan internet dan media sosial sebagai salah satu bentuk komunikasi antara satu dengan lainnya. Menurut survei data yang dilakukan oleh Asosiasi Penyelenggara Jasa internet Indonesia (APJII, 2017), didapatkan data penggunaan internet di Indonesia pada tahun 2017 telah mencapai 143,26 jutajiwa. Jumlah ini mencakup 54,68 persen dari total populasi di Indonesia yaitu 262 juta jiwa. Adapun rata-rata intensitas penggunaan media sosial masyarakat Indonesia mencapai 3 jam 23 menit per hari (We Are Social, 2018).

Seiring berkembangnya teknologi, khususnya media sosial tersebut, akhirnya dikenal istilah electronic word of mouth (eWOM) atau dapat dikenal juga sebagai ulasan online. Electronic Word-of Mouth (eWOM) adalah media baru bagi konsumen untuk memberikan ulasan ataupun mempromosikan produk atau jasa melalui situs jejaring sosial (Hennig-Thurau, Gwinner, Walsh, dan Gremler, 2004). Saat ini sudah sangat banyak orang yang membagikan eWOM atau ulasan online tersebut melalui jenis media sosial apapun, baik itu melalui blogs, social networks, content communities, maupun forums.

Di Indonesia cukup banyak dapat ditemukan ulasan tentang produk makanan, terutama produk kuliner milik artis yang sedang marak di Indonesia saat ini. Salah satu merek produk kuliner artis kekinian yang terkenal yaitu Surabaya Patata milik kakak beradik Oki Setiana Dewi dan Ria Ricis. Oki Setiana Dewi sendiri dikenal sebagai pemain film dan ustadzah, sedangkan sang adik Ria Ricis dikenal sebagai Selebgram dan Youtuber dengan jumlah subscriber terbanyak di Indonesia. Berdasarkan pada banyaknya jumlah followers dan subscribers yang dimiliki oleh Ria Ricis sebagai pemilik Surabaya Patata, dan berdasarkan jumlah followers akun Instagram Surabaya Patata, serta jumlah ulasan online Surabaya Patata, menunjukkan minat masyarakat 
terhadap Surabaya Patata cukup tinggi. Selain itu berdasarkan 4 (enam) kue kekinian artis yang ada di Surabaya, berikut peringkat rekomendasi dari ulasan yang diberikan konsumen dapat dilihat pada tabel berikut (Njajan.com dan dari berbagai sumber):

Tabel 1. Peringkat rekomendasi kue kekinian artis

\begin{tabular}{cllcc}
\hline $\begin{array}{l}\text { No. Kue kekinian } \\
\text { artis (Merek) }\end{array}$ & Pemilik & $\begin{array}{c}\text { Jumlah } \\
\text { ulasan }\end{array}$ & $\begin{array}{c}\text { Skor } \\
\text { rekomendasi }\end{array}$ \\
\hline 1 & $\begin{array}{l}\text { Surabaya } \\
\text { Patata }\end{array}$ & Oki Setiana & 2.213 & 4.2 \\
& $\begin{array}{l}\text { Dewi \& } \\
\text { Ria Ricis }\end{array}$ & & \\
2 & Surabaya Snow & Zaskia \\
Cake & Sungkar \& & 1.206 & 4.4 \\
& & & \\
3 & Vallens Cake & Irwansyah & & \\
4 & Vidi Vallen & 100 & 4.1 \\
& Surabaya & Aldiano & 14 & 4.4 \\
\hline
\end{tabular}

Berdasarkan tabel di atas, dapat dilihat bahwa Surabaya Patata ada pada peringkat paling atas dengan jumlah ulasan paling banyak yaitu 2.213 dengan skor rekomendasi 4.2. Jika dibandingkan dengan kue kekinian artis yang ada di Surabaya, perbedaan jumlah ulasannya signifikan. Berbeda dengan skor rekomendasi yang paling tinggi yaitu 4.4 diperoleh Surabaya Snow Cake, Vidi Vini Vici dan Bolu Djoeang Surabaya. Namun untuk skor rekomendasi Surabaya Patata memperoleh 4.2 yang tidak berbeda jauh dengan skor rekomendasi tertinggi yaitu 4.4. Berdasarkan data tersebut penulis tertarik untuk menggunakan ulasan online Surabaya Patata pada penelitian ini.

Menurut Chakraborty dan Bhat (2018), dari banyaknya ulasan online yang dapat ditemukan di media sosial, tidak semua ulasan online dapat dipercaya begitu saja. Hal ini menyebabkan konsumen lebih memilih untuk mempercayai ulasan yang memiliki tingkat kredibilitas yang tinggi. Persepsi konsumen mengenai kredibilitas ulasan online dapat dipengaruhi oleh dua faktor yaitu, faktor penentu informasi dan normatif. Faktor penentu informasi terdiri dari argument strength, recommendation framing, recommendation sidedness, source credibility, dan confirmation of prior belief. Sedangkan faktor penentu normatif terdiri dari recommendation consistency dan recommendation rating.

Penelitian terdahulu yang dilakukan oleh Cheng, Luo, Sia, dan Chen (2009) dengan judul "Credibility of Electronic Word-of-Mouth: Informational and Normative Determinants of On-line Consumer Recommendations" membuktikan bahwa faktor penentu informasi argument strength, source credibility, dan confirmation of prior belief berpengaruh signifikan terhadap perceived eWOM credibility. Hasil penelitian juga menunjukkan faktor penentu normatif yaitu recommendation consistency dan recommendation rating secara signifikan mempengaruhi konsumen menentukan kredibilitas eWOM. Pada penelitian ini penulis menguji kembali penelitian terdahulu, tetapi dengan obyek yang berbeda yaitu Surabaya Patata.

\section{TINJAUAN PUSTAKA}

\section{Electronic Word of Mouth (eWOM)}

eWOM adalah proses pertukaran informasi yang dinamis dan berkelanjutan antara konsumen potensial, konsumen aktual, atau konsumen terdahulu mengenai produk, layanan, merek, atau perusahaan, yang tersedia untuk banyak orang dan lembaga melalui internet. Komunikasi eWOM dilakukan hanya melalui jaringan internet, sehingga komunikasi eWOM memiliki ikatan yang tidak begitu kuat dan peninjau (reviewer) kebanyakkan tidak diketahui (Ismagilova, Slade, Dwivedi, dan Williams, 2017). Hal tersebut yang menyebabkan tidak semua eWOM dapat dipercaya begitu saja (Chakraborty dan Bhat, 2018), dan ada beberapa faktor yang dapat mempengaruhi penilaian konsumen terhadap kredibilitas dari eWOM atau ulasan online.

\section{Faktor Penentu eWOM}

Menurut Cheung et al., (2009), faktor penentu eWOM untuk dapat dikatakan sebagai eWOM yang memiliki kredibilitas dapat dijelaskan melalui faktor penentu informasi dan faktor penentu normatif. Berdasarkan Yale model terdapat tiga faktor penentu informasi yang utama untuk mengevaluasi kredibilitas eWOM yaitu sumber, pesan, dan penerima (Cheung et al., 2009). Sumber adalah orang yang mengunggah ulasan online. Kredibilitas sumber merupakan ukuran untuk mengevaluasi kredibilitas sumber informasi. Kredibilitas pesan adalah kredibilitas konten ulasan online yang dapat dinilai dari argument strength, recommendation framing, dan recommendation sidedness. Pembaca adalah orang yang melihat ulasan online yang dapat dinilai dari confirmation of prior belief (Chakraborty dan Bhat, 2018).

1. Argument strength

Argument strength merupakan kualitas dari informasi yang diterima, menilai sejauh mana pembaca ulasan online melihat argumen tersebut meyakinkan atau benar dalam mendukung ulasannya (Cheung et al, 2009). Luo, Luo, Xu, Warkentin, dan Sia (2015) dalam penelitiannya, untuk mengukur argument strength menggunakan salah satu 
indikator yaitu, masuk akal tidaknya argumen yang disampaikan oleh reviewer. Sedangkan Zhang (1996), pada penelitiannya yang menyelidiki dampak dari humor dalam periklanan dan adanya keterlibatan dari need for cognition (NFC) agar humor menjadi lebih efektif dalam periklanan, menggunakan skala diferensial semantik yang terdiri dari empat pasang ajektiva bipolar untuk mengukur argument strength. Empat pasang ajektiva bipolar tersebut, yaitu 1) Argumen yang lemah - argumen yang kuat, 2). Tidak persuasif persuasif, 3). Tidak meyakinkan - meyakinkan dan 4). Argumen yang baik - argumen yang buruk. Berdasarkan hasil penelitian dari Cheung et al., (2009) kekuatan argumen berpengaruh signifikan terhadap kredibilitas eWOM. Jika informasi yang diberikan memiliki argumen yang valid maka konsumen akan menganggap informasi itu dapat dipercaya. Hal ini membuktikan kekuatan argumen merupakan elemen penting yang digunakan konsumen untuk menilai kredibilitas eWOM. Hasil penelitian lain yang mendukung hal tersebut yaitu, Chakraborty dan Bhat (2018), dan Cheung, Sia, dan Kuan (2012) didapatkan argument strength memiliki berpengaruh positif dan signifikan signifikan terhadap perceived eWOM credibility. Dengan demikian hipotesa yang diajukan pada penelitian ini adalah:

H1: Argument strength berpengaruh positif dan signifikan terhadap perceived eWOM credibility pada ulasan online Surabaya Patata

\section{Recommendation framing}

Recommendation framing berhubungan dengan valence eWOM, baik itu dikelompokkan secara positif atau dikelompokkan secara negatif (Cheung et al, 2009). Pada penelitian yang dilakukan oleh Lopez dan Sicilia, (2014), yang juga melakukan pengujian faktor-faktor penentu pengaruh eWOM pada turis atau travelers, menggunakan recommendation framing (valence) sebagai salah satu variabel yang diukur. Untuk mengukur recommendation framing (valence) atau dikenal sebagai perceived valence dalam penelitian Lopez dan Sicilia, (2014) menggunakan dua indikator. Lopez dan Sicilia, (2014) mengadopsi indikator tersebut dari Park, Lee, dan Han, (2007), kedua indikator tersebut mengukur recommendation framing (valence) melalui 1). Keseluruhan ulasan merekomendasikan atau tidak merekomendasikan produk dan 2). Evaluasi produk bersifat positif atau negatif.
Rangkaian informasi berupa informasi positif atau informasi negatif dapat mempengaruhi perceived eWOM credibility. Menurut Cheung et al., (2009), eWOM yang bersifat negatif lebih dianggap kredibel dibandingkan eWOM yang bersifat positif. Hal ini mungkin terjadi karena informasi negatif mengurangi kemungkinan bahwa ulasan tersebut diunggah oleh orang yang ingin mempromosikan produk tersebut. Berdasarkan penelitian Cheung, Lee, dan Rabjohn (2008) recommendation framing yang negatif memiliki pengaruh dan signifikan terhadap perceived eWOM credibility.

$\mathrm{H} 2$ : Recommendation Framing berpengaruh positif dan signifikan terhadap perceived eWOM credibility pada ulasan online Surabaya Patata.

\section{Recommendation Sideness}

Recommendation Sideness menurut Cheung et al., (2009) dapat diukur melalui sisi pesan yang disampaikan, yaitu apakah pesan yang disampaikan hanya satu sisi saja (one-sided message) menyampaikan kekurangan atau kelebihannya saja dari sebuah produk maupun jasa, atau menampilkan dua sisi (two-sided message) yaitu menyampaikan kelebihan dan kekurangan dari sebuah produk maupun jasa.

Ulasan yang menunjukkan dua aspek yaitu positif (kelebihan) dan negatif (kekurangan) dari suatu produk dapat lebih dipercaya dibandingkan dengan ulasan dengan satu aspek saja. Dalam pikiran konsumen setiap produk memiliki kelebihan dan kekurangan masing-masing, sehingga dengan adanya informasi tentang dua aspek tersebut akan meningkatkan kredibilitas mengenai informasi produk yang diulas (Cheung et al., 2009). Chakraborty dan Bhat, (2018) menyatakan ulasan dengan dua aspek lebih mempengaruhi perceived eWOM credibility daripada ulasan dengan satu aspek. Hal ini dibuktikan dari hasil penelitian Cheung, Sia, dan Kuan (2012) recommendation sidedness memiliki pengaruh yang positif dan signifikan.

H3: Recommendation sidedness berpengaruh positif dan signifikan terhadap perceived eWOM credibility pada ulasan online Surabaya Patata.

4. Source Credibility

Source Credibility adalah persepsi pembaca ulasan online mengenai keahlian sumber (source expertise) dan kepercayaan sumber (source trustworthiness) (Luo, Luo, Xu, Warkentin, dan Sia, 2015). Menurut Cheung, Lee, dan Rabjohn, (2008), kredibilitas sumber didukung oleh 2 faktor utama yaitu 1). Source Expertise (keahlian sumber) 
adalah keahlian sumber yang mengacu pada pengetahuan, keterampilan maupun pengalaman yang dimiliki oleh reviewer, sehingga dapat memberikan informasi yang akurat dan 2). Source Truwstworthiness (kepercayaan sumber) adalah kepercayaan sumber yang mengacu pada keyakinan terhadap reviewer mengenai keobjektifan dan kejujuran reviewer dalam memberikan ulasan. Kredibilitas sumber dapat diartikan sebagai keahlian atau motivasi untuk memberikan informasi yang akurat dan jujur (Cheung dan Thadani, 2012). Pembaca ulasan online akan lebih mempercayai dan lebih mudah menerima informasi dari sumber dengan kredibilitas yang tinggi, dibandingkan sumber yang memiliki kredibilitas rendah. Ulasan yang diberikan oleh sumber yang memiliki kredibilitas tinggi dianggap lebih bermanfaat dan dapat diandalkan (Cheung, Lee, dan Rabjohn, 2008). Hal ini dibuktikan dari hasil penelitian (Cheung et al. 2009; Chakraborty dan Bhat, 2018; Cheung, Sia, dan Kuan, 2012, dan Lis, 2013) bahwa source credibility berpengaruh positif dan signifikan terhadap perceived eWOM credibility.

H4: Source credibility berpengaruh positif dan signifikan terhadap perceived eWOM credibility pada ulasan online Surabaya Patata.

5. Confirmation of prior belief

Confirmation of prior belief yaitu sejauh mana informasi tersebut dianggap benar dengan mendeteksi tingkat kesamaan antara informasi yang diterima dengan persepsi pembaca ulasan online itu sendiri terhadap produk maupun jasa yang diberikan melalui pengalaman langsung maupun tidak langsung (Cheung et al, 2009). Menurut Cheung et al., (2009), confirmation prior of belief ini dapat diukur melalui kesan maupun informasi yang dimiliki oleh pembaca ulasan online terhadap produk sebelumnya. Pengaruh normatif muncul ketika informasi yang diberikan disukai atau dapat diterima oleh orang lain (Cheung et al., 2009). Dalam eWOM terdapat dua faktor penentu normatif yaitu 1). Recommendation consistency mengindikasikan sejauh mana eWOM yang saat ini direkomendasikan pembaca konsisten dengan evaluasi dari kontributor eWOM lainnya terkait produk maupun jasa yang sama. Menurut Cheung et al. (2009) dan Luo et al., (2015), recommendation consistency dapat diukur melalui konsistensi, kemiripan, dan kesesuaian antara satu ulasan dengan lainnya, terkait produk maupun jasa yang sama dan 2). Recommendation rating mengindikasikan keseluruhan penilaian yang diberikan oleh pembaca lainnya terhadap ulasan online tersebut. Jika kebanyakan pembaca memberikan nilai yang tinggi, maka artinya kebanyakan pengguna setuju dan mempercayai isi dari ulasan tersebut (Cheung et al., 2009). Jika ulasan online menegaskan keyakinan konsumen yang sudah ada sebelum melihat ulasan tersebut, maka konsumen akan lebih mempercayai informasi itu. Sebaliknya jika hasil ulasan online tidak sesuai dengan keyakinan konsumen, maka konsumen cenderung menolak untuk mempercayai informasi tersebut, karena konsumen cenderung lebih dapat menerima dan mempercayai informasi yang mirip dengan keyakinan konsumen. Berdasarkan hasil penelitian Cheung et al., (2009) confirmation of prior belief berpengaruh positif dan signifikan terhadap perceived eWOM credibility.

H5: Confirmation of prior belief berpengaruh positif dan signifikan terhadap perceived eWOM credibility pada ulasan online Surabaya Patata.

\section{Recommendation Consistency}

Recommendation consistency mengindikasikan sejauh mana eWOM yang dibaca saat ini konsisten dengan evaluasi dari kontributor eWOM lainnya terkait produk maupun jasa yang sama. Jika rekomendasi saat ini konsisten dengan pendapat pengguna yang lain, maka pembaca ulasan online menganggap informasi tersebut lebih terpercaya. Menurut Cheung et al., (2009) dan Luo et al., (2015), recommendation consistency dapat diukur melalui konsistensi, kemiripan, dan kesesuaian antara satu ulasan dengan lainnya, terkait produk maupun jasa yang sama. Menurut Cheung et al., (2009) jika ulasan tersebut tidak memiliki kesamaan dengan ulasan lainnya maka ulasan tersebut dianggap tidak kredibel karena membingungkan pembaca. Hasil penelitian yang telah dilakukan sebelumnya, yaitu penelitian oleh Cheung et al. (2009), Cheung, Sia, dan Kuan (2012), dan Chakraborty dan Bhat (2018) didapatkan hasil bahwa recommendation consistency memiliki pengaruh positif dan signifikan terhadap perceived eWOM credibility.

H6: Recommendation consistency berpengaruh positif dan signifikan terhadap perceived eWOM credibility pada ulasan Surabaya Patata.

\section{Perceived eWOM Credibility}

Perceived eWOM credibility adalah sejauh mana seseorang merasa rekomendasi atau ulasan yang diterima dapat dipercaya, benar, atau faktual (Tseng 
dan Fogg, 1999). Dampak dari informasi yang diterima ini dapat hanya sebatas sebagai pembelajaran atau pengetahuan. Namun kebanyakan dapat berdampak lebih besar seperti informasi tersebut dapat disebarkan kepada orang lain, digunakan untuk membuat keputusan, dan dapat mempengaruhi sikap dan perilaku (Wathen dan Burkell, 2002).

Smith dan Vogt, (1995) dalam penelitiannya mengenai dampak dari integrasi antara periklanan dan komunikasi word of mouth yang negatif terhadap pengolahan dan tanggapan pesan, menggunakan perceived eWOM credibility sebagai salah satu faktor yang mempengaruhi penerimaan pesan. Perceived eWOM credibility dapat diukur melalui tiga hal, yaitu pada tingkat kebenaran, keakuratan dan kepercayaan terhadap eWOM.

\section{Kerangka Pemikiran}

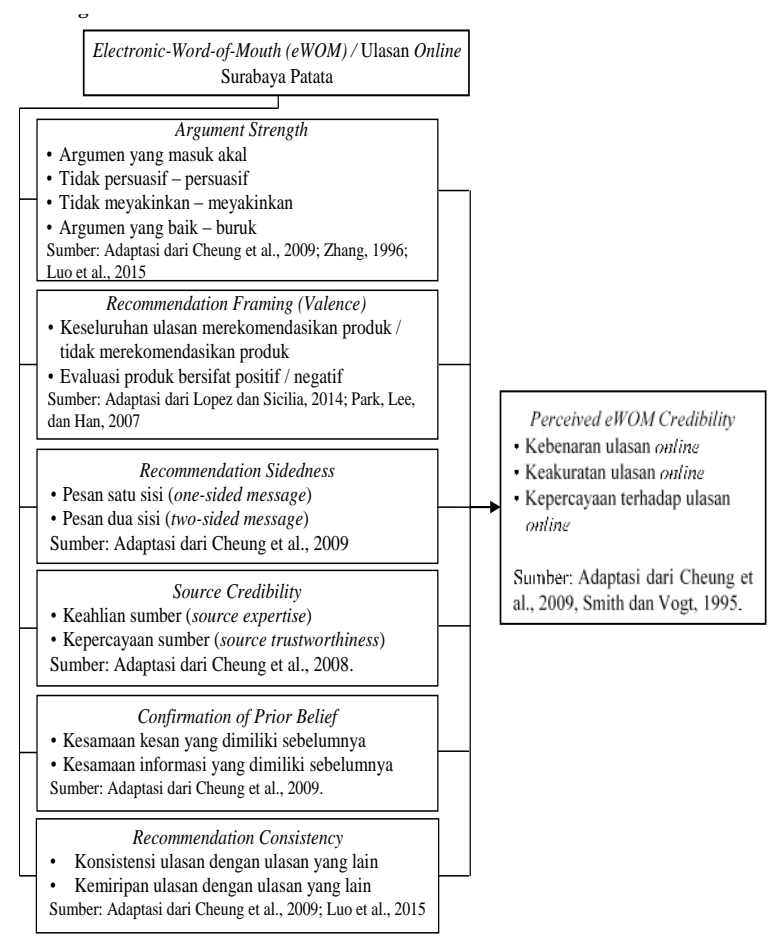

Gambar 1. Kerangka Pemikiran

\section{METODE PENELITIAN}

Sasaran penelitian ini adalah masyarakat Indonesia yang membaca ulasan online mengenai Surabaya Patata sebagai sumber informasi untuk mengetahui lebih banyak informasi terkait Surabaya Patata. Teknik pengambilan sampel penelitian ini nonprobability sampling jenis purposive sampling, dengan menetapkan beberapa kriteria tertentu yaitu minimal berusia 17 tahun dan telah membaca ulasan online Surabaya Patata lebih dari satu ulasan.
Data dikumpulkan melalui penyebaran kuesioner online melalui media sosial seperti Instagram, Twitter, Line, Whatsapp dan Facebook. Jumlah sampel yang didapatkan pada penelitian ini adalah sebanyak 176 responden, namun hanya sebanyak 125 data responden yang dapat digunakan datanya untuk penelitian lebih lanjut. Teknik pengolahan data pada penelitian ini menggunakan analisa regresi linear berganda.

\section{HASIL PENELITAN DAN PEMBAHASAN}

Analisa data merupakan tahapan yang penting untuk mencapai tujuan penelitian ini yaitu untuk mengukur pengaruh kelima variabel bebas terhadap variabel terikat yaitu perceived eWOM credibility. Tahap pengujian validitas dan reliabilitas dilakukan sebelum pengolahan data untuk memastikan bahwa butir-butir indikator mampu mengukur apa yang harus diukur.

\section{Hasil Uji Validitas dan Reliabilitas}

Kuesioner dinyatakan valid jika $r_{\text {hitung }}>r_{\text {tabel }}$ atau jika nilai signifikansi lebih kecil dari 0,05 (Ghozali, 2012). Nilai $r_{\text {tabel }}$ untuk $n=30$ adalah sebesar 0,361 . Berdasarkan tabel 2, ada tiga butir yang tidak valid sehingga tidak digunakan pada penelitian ini.

Tabel 2. Hasil Uji Validitas

\begin{tabular}{lcccc}
\hline \multicolumn{1}{c}{ Variabel } & Indikator & $\begin{array}{c}\mathbf{r} \\
\text { hitung table }\end{array}$ & Sig. & Keterangan \\
\hline Argument & $\mathrm{X} 1.1$ & $0,7890,361$ & 0,00 & Valid \\
Strength & $\mathrm{X} 1.2$ & $0,6050,361$ & 0,00 & Valid \\
& $\mathrm{X} 1.3$ & $0,5650,361$ & 0,001 & Valid \\
& $\mathrm{X} 1.4$ & $0,7650,361$ & 0,00 & Valid \\
Recommen- & $\mathrm{X} 2.1$ & $0,5360,361$ & 0,002 & Valid \\
dation & $\mathrm{X} 2.2$ & $0,2630,361$ & 0,161 & Tidak Valid \\
Framing & $\mathrm{X} 2.3$ & $0,4680,361$ & 0,009 & Valid \\
& $\mathrm{X} 2.4$ & $0,4780,361$ & 0,008 & Valid \\
Recommendati & $\mathrm{X} 3.1$ & $0,7640,361$ & 0,00 & Valid \\
on Sidedness & $\mathrm{X} 3.2$ & $0,5270,361$ & 0,003 & Valid \\
& $\mathrm{X} 3.3$ & $0,1770,361$ & 0,349 & Tidak Valid \\
Source & $\mathrm{X} 4.1$ & $0,6750,361$ & 0,00 & Valid \\
Credibility & $\mathrm{X} 4.2$ & $0,7680,361$ & 0,00 & Valid \\
& $\mathrm{X} 4.3$ & $0,6790,361$ & 0,00 & Valid \\
Confirmataion & $\mathrm{X} 5.1$ & $0,7030,361$ & 0,00 & Valid \\
of Prior Belief & $\mathrm{X} 5.2$ & $0,6300,361$ & 0,00 & Valid \\
& $\mathrm{X} 5.3$ & $0,3540,361$ & 0,055 & Tidak Valid \\
Recommendati & $\mathrm{X} 6.1$ & $0,8500,361$ & 0,00 & Valid \\
on Consistency & $\mathrm{X} 6.2$ & $0,8620,361$ & 0,00 & Valid \\
Perceived & $\mathrm{Y} .1$ & $0,8790,361$ & 0,00 & Valid \\
eWOM & $\mathrm{Y} .2$ & $0,8790,361$ & 0,00 & Valid \\
Credibility & $\mathrm{Y} .3$ & $0,8840,361$ & 0,00 & Valid \\
\hline \multirow{2}{*}{ Con } & & & \multicolumn{3}{c}{} \\
\end{tabular}


Untuk mengukur realibilitas kuesioner, dapat dilihat pada nilai Cronbach 's alpha. Jika nilai koefisien Cronbach's Alpha $(\alpha)$ atau koefisien yang diperoleh $\geq$ 0,60 maka kuesioner dapat dikatakan reliable (Ghozali, 2012).

Tabel 3. Hasil Uji Reliabilitas

\begin{tabular}{lccc}
\hline \multicolumn{1}{c}{ Variabel } & $\begin{array}{c}\text { Nilai } \\
\text { Cronbach } \\
\text { Alpha }\end{array}$ & $\begin{array}{c}\text { Nilai } \\
\text { Kritis }\end{array}$ & Keterangan \\
\hline $\begin{array}{l}\text { Argument Strength } \\
\text { Recommendation }\end{array}$ & 0,617 & 0,60 & Reliabel \\
$\begin{array}{l}\text { Framing } \\
\text { Recommendation }\end{array}$ & 0,753 & 0,60 & Reliabel \\
$\begin{array}{l}\text { Sidedness } \\
\text { Source Credibility }\end{array}$ & 0,647 & 0,60 & Reliabel \\
$\begin{array}{l}\text { Confirmation of Prior } \\
\text { Belief }\end{array}$ & 0,663 & 0,60 & Reliabel \\
$\begin{array}{l}\text { Recommendation } \\
\text { Consistency }\end{array}$ & 0,636 & 0,60 & Reliabel \\
$\begin{array}{l}\text { Perceived eWOM } \\
\text { Credibility Surabaya }\end{array}$ & 0,856 & 0,60 & Reliabel \\
Patata & & & \\
\hline
\end{tabular}

\section{Analisa Profil Responden}

Pada penelitian ini mayoritas responden adalah perempuan yaitu sebanyak 95 orang $(76 \%)$, sedangkan responden laki-laki sebanyak 30 orang (24\%). Mayoritas responden memiliki pendidikan akhir SMA atau SMK yaitu sebanyak 79 orang $(63,2 \%)$, sedangkan minoritas responden memiliki pendidikan akhir strata 2 sebanyak 2 orang $(1,6 \%)$. Pekerjaan responden mayoritas adalah pelajar atau mahasiswa, sebanyak 95 orang $(76 \%)$, sedangkan pekerjaan minoritas responden adalah pekerjaan lain-lainnya yang tidak disebutkan pada pilihan, yaitu sebanyak 1 orang $(0,7 \%)$. Usia mayoritas responden adalah berusia 17-25 tahun sebanyak 114 orang $(91,2 \%)$, usia minoritas adalah 26 35 tahun sebanyak 11 orang $(8,8 \%)$. Jenis media yang digunakan oleh responden untuk membaca ulasan online Surabaya Patata mayoritas menggunakan Instagram yaitu sebanyak 95 orang $(53,7 \%)$, dan minoritas ada Twitter yaitu sebanyak 4 orang $(2,3 \%)$.

\section{Analisa Deskriptif Penilaian Responden}

Pada pembahasan penelitian ini dijelaskan tentang rata-rata tanggapan responden terhadap indikatorindikator variabel secara keseluruhan serta jumlah responden yang memberikan jawaban terhadap masing-masing indikator variabel.

\section{Variabel Argument Strength (X1)}

Tabel 4. Tanggapan Responden untuk Variabel Argument Strength $(\mathrm{X} 1)$

\begin{tabular}{lccc}
\hline \multicolumn{1}{c}{ Indikator } & Mean & $\begin{array}{c}\text { Standar } \\
\text { Deviasi }\end{array}$ & $\begin{array}{c}\text { Kete- } \\
\text { rangan }\end{array}$ \\
\hline $\begin{array}{l}\text { Ulasan yang saya baca } \\
\text { meyakinkan }\end{array}$ & 3,78 & 0,728 & Setuju \\
$\begin{array}{l}\text { Ulasan yang saya baca } \\
\text { masuk akal }\end{array}$ & 3,97 & 0,782 & Setuju \\
$\begin{array}{l}\text { Ulasan yang saya baca } \\
\text { bersifat persuasif }\end{array}$ & 3,66 & 0,899 & Setuju \\
$\begin{array}{l}\text { Ulasan yang saya baca } \\
\text { berkualitas baik }\end{array}$ & 3,88 & 0,779 & Setuju \\
\hline \multicolumn{1}{c}{ Total mean } & 3,835 & & Setuju \\
\hline
\end{tabular}

2. Variabel Recommendation Framing (X2)

Tabel 5. Tanggapan Responden untuk Variabel Recommendation Framing (X2)

\begin{tabular}{|c|c|c|c|}
\hline Indikator & Mean & $\begin{array}{c}\text { Standar } \\
\text { Deviasi }\end{array}$ & $\begin{array}{c}\text { Kete- } \\
\text { rangan }\end{array}$ \\
\hline $\begin{array}{l}\text { Ulasan yang } \\
\text { disampaikan cenderung } \\
\text { bersifat positif atau } \\
\text { menyampaikan } \\
\text { kelebihan dari Surabaya } \\
\text { Patata }\end{array}$ & 3,90 & 0,865 & Setuju \\
\hline $\begin{array}{l}\text { Secara keseluruhan, } \\
\text { reviewer } \\
\text { merekomendasikan } \\
\text { Surabaya Patata }\end{array}$ & 3,77 & 0,844 & Setuju \\
\hline Total mean & 3,835 & & Setuju \\
\hline
\end{tabular}

3. Variabel Recommendation Sidedness (X3)

Tabel 6. Tanggapan Responden untuk Variabel Recommendation Sidedness (X3)

\begin{tabular}{lccc}
\hline \multicolumn{1}{c}{ Indikator } & Mean & $\begin{array}{c}\text { Standar } \\
\text { Deviasi }\end{array}$ & $\begin{array}{c}\text { Kete- } \\
\text { rangan }\end{array}$ \\
\hline $\begin{array}{l}\text { Ulasan yang saya baca } \\
\text { menyatakan kelebihan } \\
\text { dan kekurangan dari }\end{array}$ & 3,72 & 0,980 & Setuju \\
$\begin{array}{l}\text { Surabaya Patata } \\
\text { Ulasan yang } \\
\text { menyampaikan dua }\end{array}$ & 3,74 & 0,952 & Setuju \\
$\begin{array}{l}\text { aspek (kekurangan dan } \\
\text { kelebihan) dari }\end{array}$ & & & \\
$\begin{array}{l}\text { Surabaya Patata lebih } \\
\text { dapat dipercaya }\end{array}$ & & & \\
\hline \multicolumn{1}{c}{ Total mean } & 3,835 & & \\
\hline
\end{tabular}




\section{Variabel Source Credibility (X4)}

Tabel 7. Tanggapan Responden untuk Variabel Source Credibility (X4)

\begin{tabular}{lccc}
\hline \multicolumn{1}{c}{ Indikator } & Mean & $\begin{array}{c}\text { Standar } \\
\text { Deviasi }\end{array}$ & $\begin{array}{c}\text { Kete- } \\
\text { rangan }\end{array}$ \\
\hline $\begin{array}{l}\text { Menurut saya reviewer } \\
\text { memiliki pengetahuan } \\
\text { untuk mengevaluasi }\end{array}$ & 3,69 & 0,846 & Setuju \\
$\begin{array}{l}\text { Surabaya Patata } \\
\text { Menurut saya reviewer } \\
\text { ahli untuk mengevaluasi } \\
\text { kualitas Surabaya Patata }\end{array}$ & 3,44 & 0,856 & Setuju \\
$\begin{array}{l}\text { Menurut saya, reviewer } \\
\text { dapat dipercaya dalam } \\
\text { mengulas Surabaya }\end{array}$ & 3,70 & 0,795 & Setuju \\
$\begin{array}{l}\text { Patata } \\
\text { Menurut saya reviewer } \\
\text { dapat diandalkan dalam } \\
\text { mengulas Surabaya }\end{array}$ & 3,66 & 0,751 & Setuju \\
\begin{tabular}{l} 
Patata \\
\multicolumn{1}{c}{ Total mean }
\end{tabular} & 3,835 & & Setuju \\
\hline
\end{tabular}

\section{Variabel Confirmation of Prior Belief(X5)}

Tabel 8. Tanggapan Responden untuk Variabel Confirmation of Prior Belief (X5)

\begin{tabular}{|c|c|c|c|}
\hline Indikator & Mean & $\begin{array}{l}\text { Standar } \\
\text { Deviasi }\end{array}$ & $\begin{array}{l}\text { Kete- } \\
\text { rangan }\end{array}$ \\
\hline $\begin{array}{l}\text { Ulasan yang saya baca } \\
\text { memperkuat informasi } \\
\text { yang saya ketahui } \\
\text { sebelumnya mengenai } \\
\text { Surabaya Patata }\end{array}$ & 3,94 & 0,830 & Setuju \\
\hline $\begin{array}{l}\text { Ulasan yang saya baca } \\
\text { mendukung kesan saya } \\
\text { sebelum membaca } \\
\text { ulasan online terkait } \\
\text { Surabaya Patata }\end{array}$ & 3,86 & 0,810 & Setuju \\
\hline Total mean & 3,835 & & Setuju \\
\hline
\end{tabular}

\section{Variabel Recommendation Consistency (X6)}

Tabel 9. Tanggapan Responden untuk Variabel Recommendation Consistency (X6)

\begin{tabular}{|c|c|c|c|}
\hline Indikator & Mean & $\begin{array}{c}\text { Standar } \\
\text { Deviasi }\end{array}$ & $\begin{array}{c}\text { Kete- } \\
\text { rangan }\end{array}$ \\
\hline $\begin{array}{l}\text { Semua ulasan yang } \\
\text { saya baca memberikan } \\
\text { tanggapan yang } \\
\text { konsisten terkait } \\
\text { Surabaya Patata }\end{array}$ & 3,69 & 0,766 & Setuju \\
\hline $\begin{array}{l}\text { Semua isi ulasan yang } \\
\text { saya baca kurang lebih } \\
\text { sama. }\end{array}$ & 3,66 & 0,879 & Setuju \\
\hline Total mean & 3,835 & & Setuju \\
\hline
\end{tabular}

\section{Variabel Perceived eWOM Credibility $(\mathrm{Y})$}

Tabel 10. Tanggapan Responden untuk Variabel Perceived eWOM Credibility (Y)

\begin{tabular}{lccc}
\hline \multicolumn{1}{c}{ Indikator } & Mean & $\begin{array}{c}\text { Standar } \\
\text { Deviasi }\end{array}$ & $\begin{array}{c}\text { Kete- } \\
\text { rangan }\end{array}$ \\
\hline $\begin{array}{l}\text { Saya merasa ulasan } \\
\text { yang saya baca } \\
\text { disampaikan dengan } \\
\text { jujur }\end{array}$ & 3,71 & 0,831 & Setuju \\
$\begin{array}{l}\text { Saya merasa ulasan } \\
\text { yang saya baca dapat } \\
\text { dipercaya }\end{array}$ & 3,72 & 0,747 & Setuju \\
$\begin{array}{l}\text { Saya merasa ulasan } \\
\text { yang saya baca } \\
\text { memberikan informasi } \\
\text { yang tepat (akurat) } \\
\text { mengenai Surabaya }\end{array}$ & 3,62 & 0,769 & Setuju \\
Patata & & & \\
\hline \multicolumn{1}{c}{ Total mean } & 3,835 & & \\
\hline
\end{tabular}

\section{Hasil Analisis Regresi Linear Berganda}

Tabel 11. Hasil Analisa Regresi Linear Berganda

\begin{tabular}{lcc}
\hline \multirow{2}{*}{\multicolumn{1}{c}{ Model }} & \multicolumn{2}{c}{$\begin{array}{c}\text { Unstandardized } \\
\text { Coefficients }\end{array}$} \\
\cline { 2 - 3 } & B & Std. Error \\
\hline Constant & 2,032 & 0,999 \\
Argument Strength (X1) & 0,109 & 0,088 \\
Recommendation Framing X2) & 0,096 & 0,125 \\
Recommendation Sidedness (X3) & 0,237 & 0,095 \\
Source Credibility (X4) & 0,317 & 0,070 \\
Confirmation of Prior Belief $(\mathrm{X} 5)$ & $-0,153$ & 0,153 \\
Recommendation Consistency (X6) & 0,198 & 0,128 \\
\hline
\end{tabular}

Berikut dapat dilihat persamaan regresi linear berganda berdasarkan tabel di atas sebagai berikut:

$$
\begin{gathered}
Y=2,032+0,109 \mathrm{X} 1+0,096 \mathrm{X} 2+0,237 \mathrm{X} 3+ \\
0,317 \mathrm{X} 4-0,153 \mathrm{X} 5+0,198 \mathrm{X} 6
\end{gathered}
$$

Berdasarkan hasil analisa regresi linear berganda dapat dilihat bahwa koefisien konstanta $(\alpha)$ dari Perceived eWOM Credibility adalah sebesar 2,032, yang menunjukkan jika variabel bebasnya konstan atau tidak ada Perceived eWOM Credibility memiliki nilai 2,032. Jika dilihat secara keseluruhan, variabel yang memiliki nilai koefisien regresi yang tertinggi adalah variabel Source Credibility $\left(\beta_{4}\right)$, yaitu sebesar 0,317. Hal ini menunjukkan Source Credibility memberikan pengaruh yang paling besar terhadap Perceived eWOM Credibility dibandingkan dengan variabel bebas lainnya yang diteliti pada penelitian ini. Nilai koefisien regresi variabel Source Credibility $\left(\beta_{4}\right)$ 
sebesar 0,317 menunjukkan jika variabel Source Credibility naik satu satuan, maka variabel Perceived eWOM Credibility akan meningkat sebesar 0,317. Berdasarkan hasil analisa regresi linear berganda juga dapat diketahui bahwa lima variabel bebas yaitu Argument Strength, Recommendation Framing, Recommendation Sidedness, Source Credibility, dan Recommendation Consistency memiliki pengaruh positif terhadap Perceived eWOM Credibility. Sedangkan variabel bebas Confirmation of Prior Belief memiliki pengaruh negatif terhadap Perceived eWOM Credibility.

\section{Hasil Analisa Adjusted $R$ Square dan Koefisien Korelasi Berganda}

Tabel 12. Hasil Analisa Adjusted R Square

\begin{tabular}{|c|c|c|c|c|}
\hline Model & $R$ & $\begin{array}{c}R \\
\text { Square }\end{array}$ & $\begin{array}{c}\text { Adjusted } \\
\boldsymbol{R} \\
\text { Square }\end{array}$ & $\begin{array}{l}\text { Std. Error of } \\
\text { the Estimate }\end{array}$ \\
\hline 1 & 0,667 & 0,444 & 0,416 & 1,563 \\
\hline
\end{tabular}

Berdasarkan tabel 12, dapat dilihat bahwa keenam variabel bebas memiliki nilai adjusted $R$ square 0,416 atau $41,6 \%$. Hal ini berarti keenam variabel bebas dapat menjelaskan pengaruhnya terhadap perceived eWOM credibility sebesar $41,6 \%$ dan selebihnya $(58,4 \%)$ dijelaskan oleh faktor lainnya. Selain itu nilai koefisien korelasi (R) adalah sebesar 0,667 . Nilai tersebut menunjukkan bahwa hubungan keenam variabel bebas terhadap Perceived eWOM Credibility (Y) adalah kuat. Nilai 0,667 ini berada pada rentang 0,60-0,799, maka dapat dikatakan antar variabel bebas dan variabel terikat memiliki hubungan yang erat.

\section{Hasil Uji Kelayakan Model (Uji-F)}

Tabel 13. Hasil Pengujian Uji F

\begin{tabular}{cc}
\hline $\mathrm{F}_{\text {hitung }}$ & $\mathrm{F}_{\text {Sig. }}$ \\
\hline 15,725 & 0,000 \\
\hline
\end{tabular}

Berdasarkan hasil perhitungan dapat disimpulkan bahwa model regresi faktor penentu e-WOM terhadap perceived e-WOM credibility dianggap fit atau layak, dikarenakan nilai signifikan secara simultan dari keenam variabel bebas terhadap variabel terikat lebih kecil dari 0,05 (F-tabel signifikansi 5\%).

\section{Hasil Uji t}

Tabel 14. Hasil Pengujian Uji t

\begin{tabular}{|c|c|c|c|c|}
\hline Variabel & $t_{\text {hitung }}$ & tSig. & $t_{\text {tabel }}$ & Keterangan \\
\hline Argument Strength X1) & 1,237 & 0,219 & & $\begin{array}{c}\text { Tidak } \\
\text { Signifikan }\end{array}$ \\
\hline $\begin{array}{l}\text { Recommendation } \\
\text { Framing (X2) }\end{array}$ & 0,763 & 0,447 & & $\begin{array}{c}\text { Tidak } \\
\text { Signifikan }\end{array}$ \\
\hline $\begin{array}{l}\text { Recommendation } \\
\text { Sidedness (X3) }\end{array}$ & 2,496 & 0,014 & 1,980 & Signifikan \\
\hline Source Credibility (X4) & 4,542 & 0,000 & & Signifikan \\
\hline $\begin{array}{l}\text { Confirmation of Prior } \\
\text { Belief (X5) }\end{array}$ & $-1,005$ & 0,317 & & $\begin{array}{c}\text { Tidak } \\
\text { Signifikan }\end{array}$ \\
\hline $\begin{array}{l}\text { Recommendation } \\
\text { Consistency (X6) }\end{array}$ & 1,543 & 0,126 & & $\begin{array}{c}\text { Tidak } \\
\text { Signifikan }\end{array}$ \\
\hline
\end{tabular}

Berdasarkan tabel 14. didapatkan hasil bahwa variabel recommendation sidedness dan source credibility memiliki pengaruh yang signifikan terhadap perceived eWOM credibility karena $t_{\text {hitung }}>t_{a b e l}$, sedangkan variabel lainnya memiliki pengaruh namun tidak signifikan.

Surabaya Patata merupakan salah satu produk kuliner kekinian artis yang ada di Surabaya. Jumlah ulasannya terbanyak jika dibandingkan dengan yang lainnya hingga mencapai dua ribu lebih ulasan dengan rekomendasi yang cukup tinggi yaitu 4.2 (lihat table 1). Dengan menu pilihan yang menarik dan harga yang terjangkau mulai dari Rp. 65.000 - Rp. 68.000 per cake, seperti Green Tea Patata, Black Patata, Cheese Patata, Banana Peanut Patata Nutella Patata dan Patata Perjuangan. Surabaya Patata mendapat respon yang baik oleh konsumen Surabaya selama dua tahun terakhir melalui unggahan ulasan online.

Mengacu pada unggahan ulasan online yang diulas oleh reviewer maupun konsumen, berikut temuan variabel setelah diuji pengaruhnya terhadap perceived eWOM credibility sebagai barometer ulasan yang dapat dipercaya terkait produk Surabaya Patata. Berdasarkan tabel uji t, argument strength pada penelitian ini berpengaruh positif namun tidak signifikan terhadap perceived eWOM credibility Surabaya Patata. Sehingga, hipotesis pertama dinyatakan ditolak. Hasil penelitian ini sejalan dengan penelitian yang dilakukan oleh Luo et al. (2014). Hasil temuannya yaitu pengaruh dari argument strength terhadap keinginan seseorang untuk mengadopsi ulasan tersebut dapat juga dipengaruhi oleh jenis situs web yang digunakan oleh responden ketika membaca ulasan tersebut. 
Menurut Luo et al., (2014), ketika seseorang membaca sebuah ulasan dari sebuah situs web kormersial maka orang tersebut tidak terlalu memperhatikan argument strength pada setiap ulasan karena merasa ada campur tangan dari pihak situs web komersial dalam menampilkan ulasan yang ada pada situs web. Hal ini dikarenakan situs web komersial pasti hanya menampilkan ulasan yang berkualitas tinggi, yaitu ulasan dengan kelengkapan dan kekuatan argumen yang tinggi kepada pembaca ulasan. Mengingat pada penelitian ini Instagram merupakan media yang paling banyak digunakan oleh responden untuk melihat ulasan online mengenai Surabaya Patata, salah satu alasan argument strength memiliki pengaruh positif namun tidak signifikan terhadap perceived eWOM credibility. Melalui unggahan ulasan Surabaya Patata pada Instagram terlihat seperti unggahan yang berpotensi telah di-endorse (bersifat komersial) oleh pihak Surabaya Patata atau pihak-pihak penjual Surabaya Patata lainnya (contoh: jasa titip kuliner). Hal ini membuat ulasan tersebut akhirnya lebih sulit untuk dipercaya oleh responden walaupun responden setuju bahwa ulasan yang dituliskan oleh pengguna Instagram memang benar meyakinkan, masuk akal, persuasif, dan berkualitas baik.

Temuan berikutnya bahwa recommendation framing pada penelitian ini menunjukkan pengaruh positif namun tidak signifikan terhadap perceived eWOM credibility pada ulasan Surabaya Patata. Dengan demikian hipotesis kedua dinyatakan ditolak. Adanya perbedaan yang besar antara jumlah ulasan positif dan ulasan negatif yang dibaca oleh responden yang diduga menjadi penyebab recommendation framing berpengaruh tidak signifikan terhadap perceived eWOM credibility. Temuan ini didasari oleh penelitian terdahulu menurut Cheung et al., (2009) yang menyatakan bahwa ulasan yang negatif lebih dapat dipercaya kebenarannya oleh pembaca. Hal ini disebabkan ulasan negatif mengurangi kemungkinan bahwa ulasan tersebut diunggah oleh orang yang ingin mempromosikan produk tersebut (Cheung et al., 2009).

Pengaruh recommendation sidedness pada penelitian ini memiliki pengaruh positif. Dengan demikian hipotesis ketiga dinyatakan diterima. Pembaca ulasan online Surabaya Patata merasa ulasan yang dibaca lebih kredibel jika reviewer dapat menyatakan kedua aspek, yaitu kekurangan dan kelebihan dari produk Surabaya Patata. Hasil penelitian ini sejalan dengan penelitian yang dilakukan oleh Cheung, Sia, dan Kuan, (2012), yang menyatakan ulasan dengan dua sisi dianggap lebih tidak bias daripada ulasan dengan satu sisi.
Ulasan dengan satu sisi lebih dianggap sebagai ulasan yang bias, baik secara positif maupun negatif. Selain itu setiap pembaca ulasan memiliki tujuan utama membantu memutuskan untuk membeli produk tersebut atau tidak. Melalui ulasan yang memiliki dua sisi pembaca dapat menilai validitas informasi yang diberikan oleh reviewer, karena dianggap lebih adil dan jujur dalam menilai produk yang diulas.

Source credibility pada penelitian ini memiliki pengaruh positif dan signifikan. Hipotesis keempat dan hipotesis ketujuh dinyatakan diterima. Hasil ini sejalan dengan penelitian (Cheung et al., 2009; Lis, 2013; Chakraborty dan Bhat, 2018; dan Cheung, Sia, dan Kuan, 2012) yang membuktikan bahwa source credibility berpengaruh positif signifikan dan paling dominan terhadap perceived eWOM credibility. Berdasarkan hasil penelitian Cheung et al., (2009) pembaca yang kurang memiliki pengetahuan mengenai topik ulasan lebih bergantung pada source credibility untuk menilai kredibilitas ulasan. Sedangkan pada penelitian ini menggunakan ulasan mengenai Surabaya Patata, dimana produk ini baru ada sekitar satu setengah tahun yang lalu dan merupakan salah satu dari banyaknya produk kuliner kekinian artis. Diduga pembaca kurang memiliki pengetahuan yang cukup mengenai Surabaya Patata, sehingga pembaca lebih bergantung pada source credibility untuk menilai kredibilitas ulasan.

Untuk memastikan source credibility mempunyai pengaruh yang signifikan terhadap perceived eWOM credibility, dilakukan wawancara terhadap enam orang responden. Menurut responden tersebut pengetahuannya mengenai Surabaya Patata tidak cukup banyak. Responden mencari ulasan mengenai Surabaya Patata, dengan mencari ulasan tersebut pada akun-akun Instagram yang memang dipercayai telah berpengalaman dalam melakukan ulasan terhadap produk-produk makanan. Menurut responden ulasan yang diunggah oleh akun tersebut dapat lebih dipercaya. Hal ini dapat dilihat pada unggahan reviewer mengenai Surabaya Patata yang memiliki jumlah likes yang banyak dan reviewer tersebut memiliki followers yang banyak. Selain itu reviewer-reviewer ini juga dikenal sebagai foodstagram, atau dengan kata lain adalah pengguna yang memiliki hobi kuliner dan gemar membagikan pengalaman kuliner melalui unggahan akun Instagram.

Pengaruh confirmation of prior belief pada penelitian ini memiliki pengaruh negatif. Hipotesis kelima dinyatakan ditolak. Temuan pada penelitian ini tidak sejalan dengan penelitian Cheung et al., (2009) namun sejalan dengan penelitian Lis (2013). Penulis menduga walaupun responden setuju bahwa ulasan 
yang dibaca memperkuat informasi yang diketahui sebelumnya dan mendukung kesan responden sebelum membaca ulasan online terkait Surabaya Patata, tetapi dikarenakan responden pada penelitian ini kurang memiliki informasi dan pengetahuan mengenai Surabaya Patata, sehingga responden masih sulit untuk menilai apakah ulasan tersebut dapat dipercaya atau tidak.

Temuan dari variabel recommendation consistency pada penelitian ini memiliki pengaruh positif. Hipotesis keenam dinyatakan ditolak. Hasil penelitian ini tidak sejalan dengan penelitian Cheung et al., (2009), Cheung, Sia, dan Kuan (2012), dan Chakraborty (2018) tetapi sejalan dengan penelitian Luo et al., (2014), yang menyatakan bahwa variabel recommendation consistency tidak terlalu diperhatikan jika terdapat variabel lainnya yang lebih berpengaruh. Responden tidak terlalu mementingkan faktor recommendation consistency untuk mengevaluasi kredibilitas dari ulasan online mengenai Surabaya Patata yang telah dibacanya. Hal ini disebabkan produk yang diulas merupakan produk makanan, yaitu produk dari Surabaya Patata, yang dimana penilaian terhadap produk Surabaya Patata sangatlah bersifat subyektif yang mengakibatkan penilaian setiap orang terhadap Surabaya Patata pasti berbeda-beda menurut selera masing-masing individu. Dengan demikian responden lebih memilih untuk memperhatikan faktor lainnya untuk mengevaluasi kredibilitas dari ulasan produk Surabaya Patata.

\section{SIMPULAN DAN SARAN}

\section{Kesimpulan}

Berdasarkan data penelitian ini terdapat beberapa temuan bahwa recommendation sidedness berpengaruh positif dan signifikan terhadap perceived eWOM credibility pada ulasan online Surabaya Patata. Ulasan dengan satu sisi lebih dianggap sebagai ulasan yang bias, baik secara positif maupun negatif. Selain itu dikarenakan setiap pembaca ulasan memiliki tujuan utama membantu memutuskan untuk membeli produk tersebut atau tidak, sehingga melalui ulasan yang memiliki dua sisi dapat menilai validitas informasi yang diberikan oleh reviewer, karena dianggap lebih adil dan jujur dalam menilai produk yang diulas.

Variabel lain yang mempunyai pengaruh positif dan signifikan terhadap perceived eWOM credibility pada ulasan online Surabaya Patata yaitu source credibility. Variabel ini juga merupakan variabel yang paling dominan pengaruhnya terhadap perceived eWOM credibility. Menurut responden berdasarkan wawancara pendukung terhadap enam responden menyatakan bahwa pengetahuan yang terkait Surabaya Patata tidak cukup banyak. Responden mencari ulasan mengenai Surabaya Patata pada akunakun Instagram yang memang dipercayai telah berpengalaman dalam melakukan ulasan terhadap produk-produk makanan. Ulasan yang diunggah oleh akun tersebut dapat lebih dipercaya. Hal ini dapat dilihat pada unggahan reviewer mengenai Surabaya Patata yang memiliki jumlah likes yang banyak dan reviewer tersebut memiliki followers yang banyak.

Beberapa variabel mempunyai pengaruh positif namun tidak signifikan terhadap perceived eWOM credibility pada ulasan online Surabaya Patata yaitu argument strength. Instagram merupakan media yang paling banyak digunakan oleh responden untuk melihat ulasan online mengenai Surabaya Patata. Hal ini disebabkan ulasan Surabaya Patata pada Instagram terlihat seperti unggahan yang berpotensi telah dikondisikan dan bersifat komersial oleh pihak Surabaya Patata atau pihak-pihak penjual Surabaya Patata lainnya (contoh: jasa titip kuliner). Hal ini membuat ulasan tersebut akhirnya lebih sulit untuk dipercaya oleh responden walaupun responden setuju bahwa ulasan yang dituliskan oleh pengguna Instagram memang benar meyakinkan, masuk akal, persuasif, dan berkualitas baik.

Recommendation framing berpengaruh positif namun tidak signifikan terhadap perceived eWOM credibility pada ulasan online Surabaya Patata. Dengan adanya perbedaan yang besar antara jumlah ulasan positif dan ulasan negatif yang dibaca oleh responden dan didukung oleh penelitian Cheung et al., (2009) yang menyatakan bahwa ulasan yang negatif lebih dapat dipercaya kebenarannya oleh pembaca. Hal ini disebabkan ulasan negatif mengurangi kemungkinan bahwa ulasan tersebut diunggah oleh orang yang ingin mempromosikan produk tersebut.

Confirmation of prior belief berpengaruh negatif dan tidak signifikan terhadap perceived eWOM credibility pada ulasan online Surabaya Patata. Hal ini dapat terjadi meskipun responden setuju bahwa ulasan yang dibaca memperkuat informasi yang diketahui sebelumnya dan mendukung kesan responden sebelum membaca ulasan online terkait Surabaya Patata, tetapi responden pada penelitian ini kurang memiliki informasi dan pengetahuan mengenai Surabaya Patata, sehingga responden masih sulit untuk menilai apakah ulasan tersebut dapat dipercaya atau tidak.

Recommendation consistency berpengaruh positif namun tidak signifikan terhadap perceived eWOM credibility pada ulasan online Surabaya Patata. Hal ini disebabkan oleh responden yang setuju bahwa ulasan 
Surabaya Patata yang dibaca memberikan tanggapan yang konsisten dan memiliki isi yang kurang lebih sama mengenai Surabaya Patata. Dalam hal ini variabel tersebut tidak terlalu dianggap penting untuk menilai kredibilitas ulasan online mengenai Surabaya Patata yang telah dibaca oleh responden. Mengingat produk yang diulas merupakan makanan yaitu produk dari Surabaya Patata. Penilaian terhadap produk Surabaya Patata sifatnya subyektif sehingga penilaian setiap orang terhadap Surabaya Patata bias berbedabeda menurut selera masing-masing responden.

\section{Saran}

1. Bagi Surabaya Patata

Berdasarkan hasil penelitian, menunjukkan bahwa source credibility memiliki pengaruh yang paling dominan terhadap perceived eWOM credibility, sehingga pihak Surabaya Patata lebih selektif dalam memilih publik figur yang sesuai untuk mempromosikan produk yang Surabaya Patata. Pihak manajemen yang dapat dilakukan yaitu lebih menonjolkan ulasan-ulasan positif mengenai Surabaya Patata yang disampaikan oleh kritikus makanan atau culinary expert yang memang telah dikenal oleh masyarakat luas dan telah dianggap professional dan ahli di bidangnya.

2. Bagi Penelitian Selanjutnya

Obyek penelitian dapat menggunakan media sosial yang lebih spesifik, sehingga pembahasannya lebih dapat mendalam dan dapat memberikan manfaat yang spesifik juga bagi media sosial tersebut. Alamat tautan dapat disertakan pada saat pengumpulan data kuesioner untuk kepentingan pengecekan data jika diperlukan di kemudian hari. Pada penelitian ini hanya mampu menjelaskan perceived eWOM credibility sebesar $41,6 \%$, lebih baik jika dapat menggunakan faktor-faktor lainnya atau menggunakan variabel moderating seperti sense of membership, level involvement, website attribute.

\section{DAFTAR REFERENSI}

Asosiasi Penyelenggara Jasa Internet Indonesia. (2017). Infografis penetrasi \& perilaku pengguna internet Indonesia survei 2017. Jakarta: Tekno Preneur.

Chakraborty, U., \& Bhat, S. (2018). Credibility of online reviews and its impact on brand image. Management Research Review, 41(1), 148-164.

Cheung, C.M., Lee, M., \& Rabjohn, N. (2008). The impact of electronic word-of-mouth: The adoption of online opinions in online customer communities. Journal of Internet Research, 18(3), 229-247.
Cheung, M. Y., Luo, C., Sia, C. L., \& Chen, H. (2009). Credibility of electronic word-of-mouth: Informational and normative determinants of online consumer recommendations. International Journal of Electronic Commerce, 13(4), 9-38.

Cheung, C. M., Sia, C. L., \& Kuan, K. Y. (2012). Is this review believable? a study of factors affecting the credibility of online consumer reviews from an ELM perspective. Journal of the Association for Information Systems, 13(8), 618635.

Cheung, C.M., \& Thadani, D.R. (2012). The impact of electronic word-of-mouth communication: A literature analysis and integrative model. Journal of Decision Support Systems, 54(1), 461-470.

Ghozali, I. (2012). Aplikasi analisis multivariate dengan program IBM SPSS 20 (6 ${ }^{\text {th }}$ ed.). Semarang: Badan Penerbit Universitas Diponegoro.

Hennig-Thurau, T., Gwinner, K. P., Walsh, G., \& Gremler, D. (2004). Electronic word of mouth via consumer opinion platforms: What motivates consumers to articulate themselves on the Internet, Journal of Interactive Marketing, 18(1), 38-52.

Ismagilova, E., Slade, E., Dwivedi, Y. K., \& Williams, M. D. (2017). Electronic word of mouth (eWOM) in the marketing context: A state of the art analysis and future directions. Switzerland: Springer International Publishing AG.

Kinapti, T.T. (2019,July 23). Bisnis kue Kekinian Artis 4 Ini Ada di Surabaya, Kamu Sudah Pernah Coba? Retrieved Desember 2, 2019, from https://surabaya.liputan6.com/read/4019519/bisn is-kue-kekinian-4-artis-ini-ada-di-surabayakamu-sudah-pernah-coba

Lis, B. (2013). In eWOM we trust: A framework of factors that determine the eWOM credibility. Journal of Business \& Information Systems Engineering, 5(3), 129-140.

Lopez, M. \& Sicilia, M. (2014). Determinants of EWOM influence: The role of consumers' Internet experience. Journal of Theoretical and Applied Electronic Commerce Research, 9(1), 28-43.

Luo, C., Luo, X., Xu, Y., Warkentin, M., \& Sia, C.L. (2015). Examining the moderating role of sense of membership in online review evaluations. Journal of Information Management, 52(3), 305316.

Luo, C., Wentian, L., Fu, X., Zeng, T., \& Lan, Y. (2014). Managing uncertainty eWOM: A comparison study between commercial and third party website. PACIS 2014 Proceedings, 279. 
Park, D. H., Lee, J., \& Han, I. (2007). The effect of online consumer reviews on consumer purchasing intention: The moderating role of involvement. International Journal of Electronic Commerce, 11(4), 125-148.

Resuka. (2019). Daftar Harga Menu Surabaya Patata Terbaru Desember 2019,

(https://hargamenu.net/harga-Surabaya-Patata/, diakses 2 Desember 2019).

Smith, R.E. \& Vogt, C.A. (1995). The effects of integrating advertising and negative word-of-mouth communications on message processing and response. Journal Consumer Psychology, 4(2), 133-151.
Tseng, S. \& Fogg, B.J. (1999). Credibility and computing technology. Journal of Communications of the ACM, 42(5), 39-44.

Wathen, C. N. \& Burkell, J. (2002). Believe it or not: Factors influencing credibility on the web. Journal of The America Society for Information Science and Technology, 53(2), 134-144.

We Are Social \& Hootsuite. (2018). Digital in 2018: World's internet users pass the 4 billion mark. London: We Are Social and Hootsuite.

Zhang, Y. (1996). Responses to humorous advertising: The moderating effect of need for cognition. Journal Advertising, 5(1), 15-32 